\title{
Melon Aphid or Cotton Aphid, Aphis gossypii Glover (Insecta: Hemiptera: Aphididae) ${ }^{1}$
}

John L. Capinera²

\section{Distribution}

Melon aphid occurs in tropical and temperate regions throughout the world except northernmost areas. In the United States, it is regularly a pest in the southeast and southwest, but is occasionally damaging everywhere. Because melon aphid sometimes overwinters in greenhouses, and may be introduced into the field with transplants in the spring, it has potential to be damaging almost anywhere.

\section{Life Cycle and Description}

The life cycle differs greatly between north and south. In the north, female nymphs hatch from eggs in the spring on the primary hosts. They may feed, mature, and reproduce parthenogenetically (viviparously) on this host all summer, or they may produce winged females that disperse to secondary hosts and form new colonies. The dispersants typically select new growth to feed upon, and may produce both winged (alate) and wingless (apterous) female offspring. Under high density conditions, deterioration of the host plant, or upon arrival of autumn, production of winged forms predominates.
During periods stressful to the host plant, small yellow or white forms of the aphid are also produced. Late in the season, winged females apparently seek primary hosts, and eventually both males and egg-laying (oviparous) females are produced. They mate and females deposit yellow eggs: eggs are the only overwintering form under cold conditions. Under warm conditions, a generation can be completed parthenogenetically in about seven days.

In the south, and at least as far north as Arkansas, sexual forms are not important. Females continue to produce offspring without mating so long as weather allows feeding and growth. Unlike many aphid species, melon aphid is not adversely affected by hot weather. Melon aphid can complete its development and reproduce in as little as a week, so numerous generations are possible under suitable environmental conditions.

\section{Egg}

When first deposited, the eggs are yellow, but they soon become shiny black in color. As noted previously, the eggs normally are deposited on catalpa and rose of sharon.

1. This document is EENY-173, one of the Featured Creatures series of the Entomology and Nematology Department, Cooperative Extension Service, Institute of Food and Agricultural Sciences, University of Florida. Published: November 2000. This document is also available on Featured Creatures Website at http://creatures.ifas.ufl.edu. Please visit the EDIS Website at http://edis.ifas.ufl.edu. Additional information on these organisms, including many color photographs, is available at the Entomology and Nematology Department website at http://entnemdept.ifas.ufl.edu/. 2. John L. Capinera, professor/department chairman, Entomology and Nematology Department, University of Florida, Gainesville, FL.

The Institute of Food and Agricultural Sciences (IFAS) is an Equal Employment Opportunity - Affirmative Action Employer authorized to provide research, educational information and other services only to individuals and institutions that function without regard to race, creed, color, religion, age, disability, sex, sexual orientation, marital status, national origin, political opinions or affiliations. For information on obtaining other extension publications, contact your county Cooperative Extension Service office. Florida Cooperative Extension Service / Institute of Food and Agricultural Sciences / University of Florida / Larry R. Arrington, Interim Dean 


\section{Nymph}

The nymphs vary in color from tan to gray or green, and often are marked with dark head, thorax and wing pads, and with the distal protion of the abdomen dark green. The body is dull in color because it is dusted with wax secretions. The nymphal period averages about seven days.

\section{Adult}

The wingless (apterous) parthenogenetic females are 1 to $2 \mathrm{~mm}$ in length. The body is quite variable in color: light green mottled with dark green is most common, but also occurring are whitish, yellow, pale green, and dark green forms. The legs are pale with the tips of the tibiae and tarsi black. The cornicles also are black. Small yellow forms apparently are produced in response to crowding or plant stress. Winged (alate) parthenogenetic females measure 1.1 to $1.7 \mathrm{~mm}$ in length. The head and thorax are black, and the abdomen yellowish green except for the tip of the abdomen, which is darker. The wing veins are brown. The egg-laying (oviparous) female is dark purplish green; the male is similar. The duration of the adult's reproductive period is about 15 days, and the post-reproductive period five days. These values vary considerably, mostly as a function of temperature. The optimal temperature for reproduction is reported to be about 21 to 27 degrees. C. viviparous females produce a total of about 70 to 80 offspring at a rate of 4.3 per day.

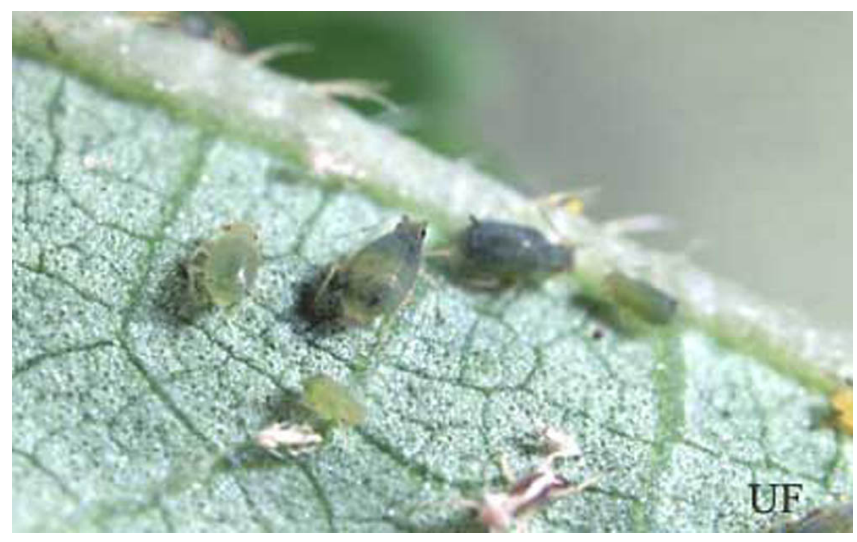

Figure 1. Melon aphids, Aphis gossypii Glover, on okra. Credits: Paul M. Choate, University of Florida

Stoetzel et al. (1996) published a key for cotton aphids that is also useful for distinguishing melon aphid from most other common vegetable-infesting aphids. One aphid commonly confused with the cotton aphid is the spirea aphid, Aphis spiraecola Patch. One means of identifying them is by examining the cauda.
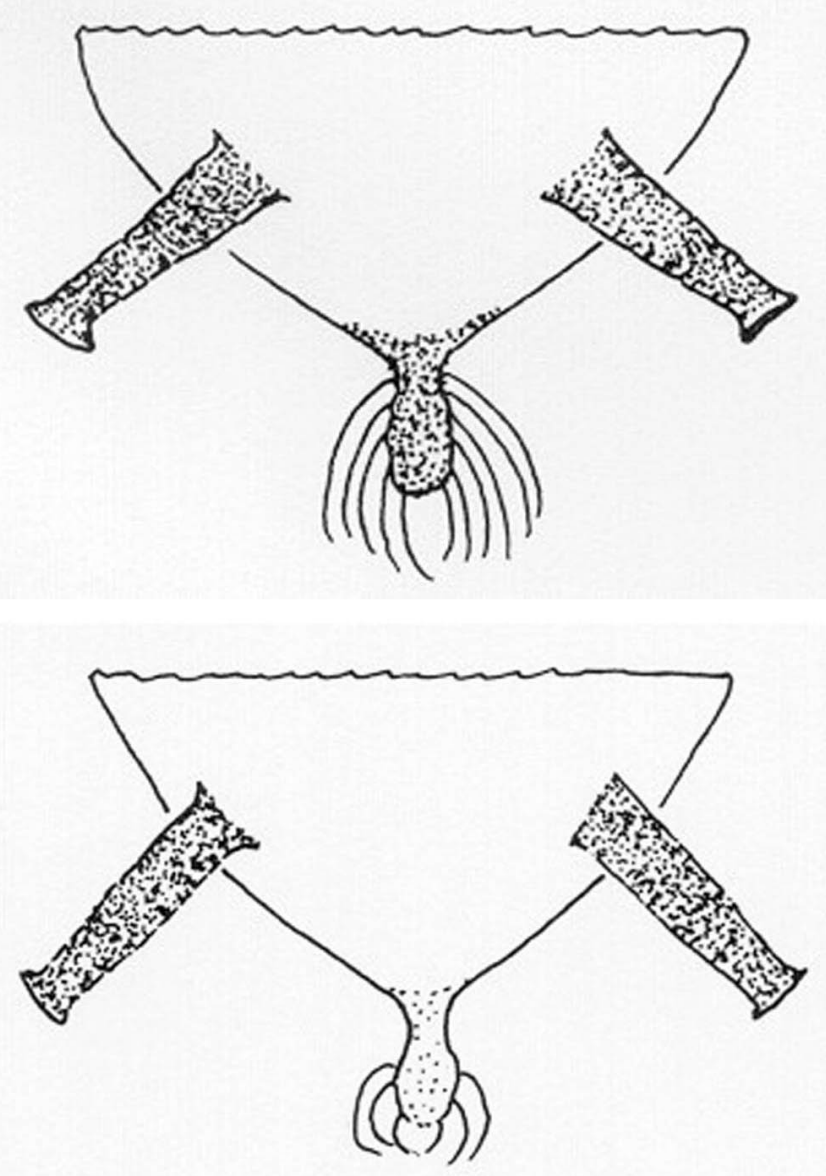

Figure 2. Other aphids are similar in appearance to Aphis gossypii (Glover), the melon or cotton aphid. One other species commonly encountered is $A$. spiraecola Patch, the spirea aphid. In $A$. gossypii (bottom) the cauda is pale to dusky and has two or three pairs of setae, in $A$. spiraecola (top) the cauda is dark brown to black and has five or six pairs of setae. Credits: Paul M. Choate, University of Florida

\section{Host Plants}

Melon aphid has a very wide host range. At least 60 host plants are known in Florida, and perhaps 700 host plants world-wide. However, the taxonomy of this species is uncertain, so some records may be incorrect. Among cucurbit vegetables, it can be a serious pest on watermelons, cucumbers, and cantaloupes, and to a lesser degree squash and pumpkin. This is the basis for the common name "melon aphid." Other vegetable crops seriously 
affected are asparagus, pepper, eggplant, and okra. Some other important crops injured regularly are citrus, cotton, and hibiscus. In the south, cotton is an important host, which explains the second common name, "cotton aphid."

The overwintering, or primary, host in cold climates was long thought to be limited to liveforever, Sedum purpureum. However, Sedum is not a host of melon aphid, but a closely related species. Rather, catalpa, Catalpa bignonioides, and rose of sharon, Hibiscus syriacus, were the overwintering hosts in northern locations. In the south, overwintering eggs are not commonly produced and overwintering hosts are more numerous, including dock, Rumex crispus; Lamium amphlexicaule; boneset, Eupatorium petaloiduem; and citrus, Citrus spp. Several researchers have noted the existence of host races; for example, aphids reared on cotton could be transferred successfully to okra but not to cucurbits. This inability to transfer to other hosts has subsequently has been shown for several other combinations.

\section{Damage}

Melon aphids feed on the underside of leaves, or on growing tip of vines, sucking nutrients from the plant. The foliage may become chlorotic and die prematurely. Their feeding also causes a great deal of distortion and leaf curling, hindering photosynthetic capacity of the plant. In addition, they secrete a great deal of honeydew which provides a substrate for growth of sooty mold, so the quality of fruit may be impaired and the photosynthetic capacity of foliage further hindered.

Melon aphid effectively transmits potyviruses, although it is only one of dozens of species implicated in the spread of plant viruses in cucurbits. Cucumber mosaic virus, watermelon mosaic virus 2, and zucchini yellow mosaic virus are transmitted despite applications of insecticide and oil sprays, probably because the viruses can be transmitted within 15 seconds.

\section{Natural Enemies}

Many of the natural enemies known to be effective against other aphids also attack melon aphid: ladybirds (Coleoptera: Coccinellidae), syrphid flies (Diptera: Syrpidae), and braconid wasps (Hymenoptera: Braconidae). Ants are commonly found associated with melon aphid but they are there to collect honeydew, and may even hinder predation by other insects. The wasp Lysiphlebus testaceipes (Cress) (Hymenoptera: Braconidae) is especially effective, sometimes causing up to $99 \%$ parasitism. Fungi also are sometimes observed to affect melon aphid.

\section{Management}

\section{Insecticides}

If insecticides are used to suppress melon aphid, care should be taken to obtain thorough cover of foliage. Leaf distortions caused by aphid feeding provide excellent shelter for the insects, so systemic insecticides are useful. Excessive and unnecessary use of insecticides should be avoided. Early in the season, aphid infestations are often spotty, and if such plants or areas are treated in a timely manner, great damage can be prevented later in the season. Use of insecticides for other, more damaging insects sometimes leads to outbreaks of melon aphid. Inadvertent destruction of beneficial insects is purported to explain this phenomenon However, resistance by melon aphid to chlorinated hydrocarbon, organophosphate, and pyrethroid insecticides is widespread.

Melon aphids will transmit viruses to crops that they do not colonize. Insecticides have little effect on virus transmission by non-colonizing, transient aphids, though insecticides can prevent secondary transmission within crops where colonization occurs.

Insect Management Guide for Vegetables (http://edis.ifas.ufl.edu/TOPIC_GUIDE_ IG_Vegetables)

Insect Management Guides for Cotton (http://edis.ifas.ufl.edu/IG059) 
Insect Management Guide for Woody

Ornamentals (http://edis.ifas.ufl.edu/IG012)

Citrus Management Guide for Aphids

(http://edis.ifas.ufl.edu/CG004)

\section{Cultural Practices}

The wide host range of melon aphid makes crop rotation a difficult tactic to implement successfully. Also, crops grown down-wind from infested fields are especially susceptible because aphids are weak fliers and tend to be blown about. Infested crops should be destroyed immediately after harvest to prevent excessive dispersal, and it may be possible to destroy overwintering hosts if they are weeds. If continuous cropping is implicated in retention of aphid populations then a crop-free period is needed. Row covers can be used to inhibit development of aphid populations. Time of planting may influence potential aphid population increase potential.

\section{Disease Transmission}

As noted above, it is difficult to disrupt transmission of nonpersistent viruses with insecticides, so total dependence on insecticides is not advised. Row covers, whitewash sprays, and reflective mulches or coarse net covers are helpful in delaying or reducing disease transmission, but this is expensive to implement on a large scale. Both aluminum and plastic mulch are reported to be useful for suppression of watermelon mosaic virus. Elimination of alternate hosts of both aphids and the virus diseases is often key to disease management; both weeds and crop plants can harbor the disease and vectors. Transmission of nonpersistent viruses such as cucumber mosaic virus can sometimes be reduced by coating the foliage with vegetable or mineral oil. Oil is postulated to inhibit virus acquisition and transmission by preventing virus attachment to the aphid's mouthparts, or to reduce probing behavior. Oil seems to be most effective when the amount of disease in an area that is available to be transmitted to a crop is at a low level. When disease inoculum or aphid densities are at high levels, oils may be inadequate protection. Also, some plants may be damaged by oil applications, especially during hot weather.

\section{Selected References}

Capinera JL. 2001. Handbook of Vegetable Pests. Academic Press, San Diego. 729 pp.

Goff CC, Tissot AN. 1932. The melon aphid, Aphis gossypii Glover. Florida Agricultural Experiment Station Bulletin 252. 23 pp.

Isely D. 1946. The cotton aphid. Arkansas Agricultural Experiment Station Bulletin 462. 29 pp.

Marco S. 1986. Incidence of aphid-transmitted virus infections reduced by whitewash sprays on plants. Phytopathology 76:1344-1348.

Perring TM, Farrar CA, Mayberry K, Blua MJ. 1992. Research reveals pattern of cucurbit virus spread. California Agriculture 46:35-39.

Romanow LR, Moyer JW, Kennedy GG. 1986. Alteration of efficiencies of acquisition and inoculation of watermelon mosaic virus 2 by plant resistance to the virus and to an aphid vector.

Phytopathology 76:1276-1281

Slosser E, Pinchak WE, Rummel DR. 1989. A review of known and potential factors affecting the population dynamics of the cotton aphid. Southwestern Entomologist 14:302-313.

Stoetzel MB, Miller GL, O'Brien PJ, Graves JB. 1996. Aphids (Homoptera: Aphididae) colonizing cotton in the United States. Florida Entomologist 79:193-205.

Webb SE, Linda SB. 1992. Evaluation of spunbounded polyethylene row covers as a method of excluding insects and viruses affecting fall-grown squash in Florida. Journal of Economic Entomology 85:2344-2352. 